\title{
The effect of trust on travel agent online use: Application of the technology acceptance model
}

\author{
Putu Yudi Setiawan $^{a^{*}}$ and Anak Agung Bagus Putu Widanta ${ }^{b}$
}

\begin{tabular}{l}
${ }^{a}$ Department of Management, Facu \\
bepartment of Economics Developm \\
\hline C H R O N I C L E \\
\hline Article history: \\
Received: March 18, 2021 \\
Received in revised format: April \\
18, 2021 \\
Accepted: June 29, 2021 \\
Available online: June 29, 2021 \\
\hline Keywords: \\
Travel Agent \\
Technology Acceptance Model \\
Trust
\end{tabular}

\section{Background}

Nowadays, shopping for travel products through Online Travel Agent (OTA) has become very popular, especially among consumers who are accustomed to placing orders suddenly. This is also supported by the increasing use of smartphones. Today's consumers benefit from ordering engines because the reservation solutions provided by OTA offer instant payment and order confirmation. OTA is an online company whose website allows consumers to order travel-related services directly via the Internet. They are third party agents that resell travel products, hotels, cars, flights, holiday packages etc. provided / organized by others. In practice, OTA has an agreement with service providers to resell their products where the OTA receives payment from consumers and then the OTA pays the net price to the provider. In the case of an agency selling tour packages, consumers issue vouchers which they must give to the tour provider to make up for the services they purchased. This voucher can be paper or electronic in the form of a mobile QR code. Once redeemed, the provider charges the agency and receives payment for the services rendered. With the growing development of the tourism industry in Indonesia, there is a significant increase in the number of Online Travel Agents (OTA). This may be due to the impact of digitization in the country and the ease with which customers feel to book hotels, flights, transportation, etc. online. According to a Google-Temasek report, Indonesia's OTA ecosystem has grown by $20 \%$ annually since 2015 . Currently, there are more than 50 OTA startups in Indonesia that offer online travel services for domestic and international tourists. In the past eight years (2010-2018), Indonesia's

* Corresponding author. Tel: +62 0361 - 229119

E-mail address: yudisetiawan@unud.ac.id (P. Y. Setiwan)

(C) 2021 by the authors; licensee Growing Science, Canada. doi: $10.5267 /$ j.ijdns.2021.6.015 
travel industry has grown exponentially. A survey conducted by DailySocial and JakPat revealed that more than $71.4 \%$ of Indonesians use OTA to plan their trips. This is also expected to grow further with President Joko Widodo's plan to make tourism a major source of foreign exchange.

Although the OTA industry in Indonesia is performing well, there are some common challenges that OTA players seem to face. One of them is a decrease in customer loyalty. Unlike traditional travel agencies which have loyal customers, OTAs have a hard time keeping customers on their platform. Since there are several OTA options available, customers can check and compare prices on various websites before choosing the best option. To make matters worse, marketers have not mastered the art of creating personalized customer journeys at multiple points of contact. Currently, the journey of customers in browsing an OTA website often does not go smoothly. In such conditions, OTA fails to create good moments for customers, which ultimately causes them to lose interest and then check other websites or applications for information (Agarwal, 2019). The Indonesian startup world now has four unicorns, one of which is Traveloka. Online Travel Agencies (OTA) activities, as a branch of e-commerce, cannot be underestimated. This is not to mention the current shift in Indonesia's lifestyle when the middle- and upper-class people spend their consumption more focused on experiences rather than on physical (material) consumption goods. Daily Social conducted a survey which aims to measure the consumption pattern of Indonesian consumers towards OTA services. The survey was asked by 2013 respondents through the JakPat Mobile Survey Platform in February 2018. Samples were taken proportionally to the population in Indonesia. The survey found that $71.44 \%$ of respondents have used OTA services for ticket / hotel reservations in the last six months. Between $50 \%-70 \%$ of respondents use Traveloka and / or Tiket.com to reserve flight tickets, train tickets, and / or hotel rooms. $83.95 \%$ of respondents use smartphones to access OTA services. $69.26 \%$ made payments for OTA services via bank / ATM account transfers (https://dailysocial.id). However, as with OTAs in general, Traveloka also faces challenges in the form of problems that can lead to decreased customer trust and loyalty. As reported by the Liputan6.com media on March 15, 2019, it was stated that there had been a dispute between the AirAsia airline and Traveloka. It was reported that AirAsia decided to withdraw flight ticket sales from the online travel agent (OTA) Traveloka. Unmitigated, this Malaysian airline canceled all flight routes. It was also stated that AirAsia Indonesia President Director Dendy Kurniawan said the withdrawal was a response to the loss of AirAsia Indonesia flights from Traveloka for the second time in the last two weeks. Problems like this will certainly affect consumer trust and perception towards Traveloka. Thus, it is considered important to conduct research to find out how the development of consumer perceptions of Traveloka as one of the OTAs in Indonesia at this time.

The model that is usually used to measure consumer or user perceptions of the benefits and ease of use of technology is known as the Technology Acceptance Model (TAM). According to Davis et al., (1989), Technology Acceptance Model can find out how users adopt new information systems in business activities. In this case, the role of technology users is determined by two perceptions, namely Perceived Usefulness and Perceived Ease of Use. Perceived Usefulness has a direct impact on the purpose of adopting technology, while Perceived Ease of Use has a direct or indirect impact on the goal of adoption through Perceived Usefulness (Davis, 1989). Consumers who use online transaction services on e-commerce have different perceptions, especially those related to the level of trust and risk. Research by Benedicktus \& Andrews (2006) reveals that to gain consumer trust, e-commerce companies are needed to maintain the company's reputation. Companies that can be trusted by consumers will encourage consumers to transact on company services. Previous research stated that an important factor needed by companies to build relationships with consumers is the trust factor (Hart \& Johnson, 1999). Thus, trust can influence consumer behavior attitudes and intentions to transact on e-commerce services. Other researchers have also stated that trust is a function of the level of risk in the context of electronic transactions (Yousafzai et al., 2003). Factors that shape consumer confidence in using transaction services in e-commerce include information accuracy, security, and privacy. In this condition, it becomes the basis for consumers that transaction services in e-commerce as a reliable medium. Based on the above problems, this research will analyze the influence of the variables of Perceived Ease of Use, Perceived Usefulness and Trust as antecedents of Attitude Toward Using (ATU) on the intention to reuse the Traveloka.com website.

\section{Literature Review}

\subsection{Theoretical background}

The Technology Acceptance Model (TAM) is a model that is built to analyze and understand the factors that influence the acceptance of the use of computer technology that was first introduced by (Davis, 1985). TAM aims to explain and estimate user acceptance of an information system. TAM provides a theoretical basis to determine the factors that affect the acceptance of a technology in an organization. TAM describes a causal relationship between belief (in the benefits of an information system and its ease of use) and the behavior, goals / needs, and actual use of the user / user of an information system. Perceived ease of use is the variety of conveniences that consumers feel in connection with the use of the internet for various purposes to be achieved (Ariyanto et al., 2020; Lui \& Jamieson, 2003) Individual perceptions regarding the ease of using computers are the level at which individuals believe that using a particular system will be error-free. This perception will then have an impact on behavior, namely the higher a person's perception of the ease of using the system, the higher the level of information technology utilization (Igbaria \& Chakrabarti, 1990). Perceived usefulness is defined as the extent to which a person believes that the use of certain information systems will improve their performance. Based on this definition, it is known that perceived usefulness is a belief about the decision-making process. If a person believes that the system is useful then he will use it. Conversely, if someone believes that information systems are less useful then he will not use them. Davis (1989) defines 
usefulness, which is a level where a person believes that the use of a particular system will be able to increase the person's work performance. Attitude toward using in TAM is conceptualized as an attitude toward using a system in the form of acceptance or rejection as an impact when someone uses a technology in their work (Fred D. Davis \& Venkatesh, 1996). Attitudes explain a person's acceptance of information technology. Hoppe et al. (2001) stated that the attitude states what we like and what we do not. A person's attitude consists of elements of cognitive, affective, and behavioral components According to Yahyapour (2008), attitude is defined as a form of evaluation of the consequences of having carried out a behavior. Attitude toward using technology is defined as an evaluation of the user's interest in using technology. using technology (Abdalla, 2007). According to the TAM theory, intention is what determines an individual's behavior to use technology. Intention, in turn, is determined by attitude. Attitude is the positive or negative value of showing a behavior. Personal attitude will determine the individual's intention to use or not use the technology. Individuals tend to use technology if they have a positive attitude. Negative attitudes, on the other hand, do not compel individuals to use technology (Davis et al., 1989).

Trust is defined as a state consisting of positive expectations from one party regarding the intentions or behavior of the other party, which does not include loss, harassment or damage caused (Rousseau, 1998). Trust has a complex composition and multi-dimensional structure. The trust that is developed during the online shopping process between the buyer and the seller plays an important role in the completion of the shopping process and in maintaining the relationship. Trust is a fundamental requirement for every business relationship and transaction. However, trust is a relatively more important requirement in online shopping than in conventional retail. This is because consumers perceive a higher level of uncertainty and increased risk in decision making when shopping online due to the unique features of online shopping settings (for example, the inability to see and feel products in real life, and no face-to-face or in-person interactions). Thus, consumer trust in online retailers and Internet technology plays an important role in online shopping behavior (Ariyanto et al., 2020; Ha \& Stoel, 2009; Kim et al., 2009). Perceived ease of use is a variable of the TAM theory. Perceived ease of use is the extent to which customers believe that shopping online can provide convenience. If a technology is perceived as easy to use, someone will choose to implement it. Arens et al. (2008) stated that the easier it is for someone to use an information system, it means that there is less effort that must be made to be able to improve its performance. The easiness that has been felt by customers when making online purchases such as easy operation of the site to be accessed, and the ease in finding the desired item will increasingly trigger someone to feel its uses and benefits so that it can influence consumers to make repurchases online. When customers find it easy to interact on online shopping sites in finding product information, how to pay online, they will feel that online shopping is useful (Wen et al., 2011). Perceived ease of use has a strong influence on perceived usefulness in online shopping (Gefen et al., 2003; Lim \& Ting, 2012). The perceived usefulness is the level of how a person believes that the use of certain technologies will increase their performance achievement (Lin \& Bhattacherjee, 2010).

Perceived usefulness is a major factor in technology acceptance, because perceived usefulness has a strong influence on intention to use technology (Davis, 1989). In research (Rehman et al., 2019; Wen et al., 2011; Yuan et al., 2016; Zhang et al., 2009) found that perceived ease of use has an effect on perceived usefulness in context. online shopping. However, Kim (2012) in his research found that perceived ease of use did not have a strong effect on perceived usefulness in the online shopping system. The perceived usefulness is a level of how a person believes that the use of certain technologies will increase their performance achievement (Lin \& Bhattacherjee, 2010). Perceived usefulness is a major factor in technology acceptance because perceived usefulness has a strong influence on intention to use technology (Davis 1989). The effect of perceived usefulness on online repurchase intentions refers to the extent to which consumers believe that online shopping will improve their transaction performance (Davis 1989). Lin and Bhattacherjee (2010) stated that the intention to buy back (Repurchase Intention) is a form of manifestation of the results of a person's evaluation of something that has been used or consumed previously. Individuals are more likely to intend to continue using when such use is deemed beneficial (Bhattacherjee, 2001; Lim et al., 2016). Consumers who have purchased products in an efficient manner are more likely to show strong repurchase intentions (Chiu et al., 2009). Research (Chiu et al., 2009; Hozhabri et al., 2014; Hung et al., 2012; Lin et al., 2010) also shows that perceived usefulness has a significant effect on online repurchase intentions. However, in the study of (Ramayah et al., 2018) found no significant effect of perceived ease of use on online repurchase intentions. In previous research using TAM, findings suggest that perceived trust positively affects ease of use and consumer attitudes. (Dahlberg et al., 2003; Ha \& Stoel, 2009; Pavlou, 2003). (Chircu et al., 2000) have found a strong correlation between perceived trust and perceived benefits. In their study investigating the intention of online banking customers to use online banking using TAM, Chau et al., (2007) incorporated the trust factor into the model. As a result, this study concludes that the trust factor has a direct effect on perceived benefits. Perceptions of consumer confidence directly and greatly influence attitudes towards online shopping. The level of trust that consumers feel in online shopping sites or practices makes shopping easier by strengthening their attitudes towards online shopping. In many studies, the perceived trust factor has been defined as a variable affecting attitudes. The desire to buy is determined by attitude (Ha \& Stoel, 2009; Kim et al., 2009). Chen et al. (2004) found that the perception of consumer trust in online stores positively affects attitudes to using online stores.

\subsection{Hypotheses}

Based on the findings in the relevant literature, a conceptual framework and hypotheses can be developed that describe the relationship between variables as below:

H1: Perceived Ease of Use has a positive and significant effect on Perceived Usefulness from the Traveloka website. 
$\mathbf{H}_{2}$ : Perceived Ease of Use has a positive and significant effect on Attitude Toward Using the Traveloka.com website.

H3: Perceived Usefulness has a positive and significant effect on Attitude Toward Using the Traveloka.com website.

H4: Trust has a positive and significant effect on Perceived Usefulness from the Traveloka website.

H5: Trust has a positive and significant effect on Attitude Toward Using the Traveloka.com website.

H6: Attitude Toward Using has a positive and significant effect on the intention to reuse the Traveloka.com website.

H7: Attitude Toward Using mediates the influence of Perceived Ease of Use, Perceived Usefulness and Trust on the intention to reuse the Traveloka.com website.

\section{Research Methods}

This research is an explanatory study, which aims to analyze and explain the relationship between the variables of Perceived Ease of Use, Perceived Usefulness and Trust as antecedents of Attitude Toward Using (ATU) to the intention to reuse the Traveloka.com website. The method used in this research is survey research method. This research is a survey research conducted on large and small populations, with the aim of producing generalizations. This research was conducted in Denpasar, considering that Denpasar is the capital of Bali Province with a high number of middle class as a potential market for the tourism industry, especially users of OTA applications. Meanwhile, the time allocated for this research is for one year, namely from the beginning of January 2020 to the end of December 2020. The population in this study is the people of the city of Denpasar, with criteria 1) People who live in Denpasar who have used the OTA Traveloka application in the last 3 years. 2) Minimum age of 20 years and a maximum of 40 years as a representation of the millennial generation, with the reason that respondents can understand well the context of the questions posed by researchers through questionnaires and relatively often use the OTA application. Based on the description above, the access population for this research is Denpasar city residents as representatives of the millennial generation, who have used the OTA Traveloka application. This research population is infinite because the number cannot be known with certainty. The sampling method in this study is non-probability sampling, judgmental sampling technique. This sampling technique is used to select respondents based on special characteristics to be sampled, which are considered relevant to predetermined population characteristics. The sample size is determined based on the rules of thumb of the analytical tool used. Because the analytical tool used in this study is Structural Equation Modeling (SEM), the minimum sample size in this study is determined by the complexity of the model and the estimation technique chosen. For research using SEM with the maximum likelihood estimation technique and a model consisting of five constructs or less, the recommended minimum sample size is the number 100-200. With these considerations, the number of samples in this study was set at 200 . The data used in this study are primary data obtained using a questionnaire data collection instrument. The primary data collected is divided into two parts, the first is data about the characteristics of the respondent such as gender, age, education, income, and so on, while the second part contains statements from the questionnaire to determine respondents' perceptions in the research variable Perceived Ease of Use, Perceived Usefulness and Trust as an antecedent of Attitude Toward Using (ATU) towards the intention to reuse the Traveloka.com website. The data collection techniques used in this study were 1) Data were collected by giving questionnaires to users of the OTA Traveloka application in Denpasar who were selected as the research sample. 2) In the preliminary study, data collection was carried out to obtain data related to the presence of potential respondents in various agencies and companies. The data collected was then taken into consideration in determining the locations of the target respondents in distributing the questionnaires. The variables of Perceived Ease of Use, Perceived Usefulness and Trust as antecedents of Attitude Toward Using (ATU) to the intention to reuse the Traveloka.com website were measured using a research instrument adapted from Sevim et al. (2017). Everything was measured using a Likert scale with a score of 1-5 ( $1=$ strongly disagree to $5=$ strongly agree $)$.

Items that appear in Table 1. This was used as material for the preparation of the questionnaire. After the questionnaire was developed, a preliminary survey of 30 respondents was carried out to assess the validity and reliability of the questionnaire that had been prepared. The validity and reliability tests of the results will be used as a consideration for revising the questionnaire prior to the actual survey. A measuring instrument can be said to have high validity if the measuring instrument is functioning properly or provides consistent measurement results with the intention of taking measurements. The validity in this study uses construct validity, by linking the total score for each question with the total score for each variable. The items on the questionnaire are valid if the correlation coefficient is positive and significant (Ghozali, 2016). Apart from being valid, the research instrument must also be reliable. a measurement instrument is said to be reliable if it can provide consistent results. Reliability shows how many measurements can give relatively different results when done back to the same subject. Reliability tests were carried out using Cronbach Alpha. The data collected is said to be reliable or reliable if it has a Cronbach Alpha coefficient value of more than 0.60. As mentioned earlier, statistical analysis of the data in this study was carried out using Structural Equation Modeling - Partial Least Square (SEM - PLS) analysis - or a variance-based structural equation model, with SmartPLS software. By using SEM - PLS, it is also possible to test the mediating effect of the intervention variables in the structural model. To determine the effect of full mediation (complete mediation), it can be seen directly from the structural model that has been analyzed. Meanwhile, to determine the effect of partial mediation, the way is to make the process run repeatedly, where in the next running process it does not include the intervention variable that tests the mediation 
effect. If the beta coefficient resulting from the direct effect on the next run is greater than the beta coefficient on the previous run, it can be stated that the tested variable has a partial mediating effect. However, if the beta coefficient on the next run is equal to or smaller than the beta coefficient on the previous run, it means that the intervening variable has no mediating effect.

For more details, it can be illustrated by a structural model consisting of variables A, B, C and D. For example, the analysis results show that $\mathrm{A}$ has a significant direct effect on $\mathrm{B}$ and $\mathrm{C}$, while $\mathrm{B}$ has a significant direct effect on $\mathrm{C}$. To determine whether B partially mediates the effect of A to C, then the run process variable B is not included in the model to be analyzed. So the model analyzed only involves variables A, C and D only. If the results then show that the beta coefficient of the direct effect of $\mathrm{A}$ to $\mathrm{C}$ is greater than when variable $\mathrm{B}$ is still involved in the actual model, it can be stated that variable $\mathrm{B}$ has a partial mediating effect. In this case it is assumed that the existing model from the real effect $\mathrm{A}$ to $\mathrm{C}$ is partially absorbed by $\mathrm{B}$. Whereas if the beta coefficient from the effect $\mathrm{A}$ to $\mathrm{C}$ remains the same or becomes smaller in value, it means that the variable $\mathrm{B}$ does not have a mediating effect in the context of $\mathrm{A}-\mathrm{B}-\mathrm{C}$.

\section{Results and Discussion}

With the advancement of technology and the development of the era, the tourism industry today cannot be separated from the digital role, where the digital world is dominated by the millennial generation, which has interesting tourist behavior. As a result, Online Travel Agents (OTA) have become the millennial generation's preferred method of booking travel, and the millennial generation has become OTA's primary target market. According to the Fig. 1., most respondents are millennials under the age of 36. Furthermore, most respondents have the most recent education, namely a high school diploma or equivalent. According to the type of work, respondents with student status outnumber those with other types of work.
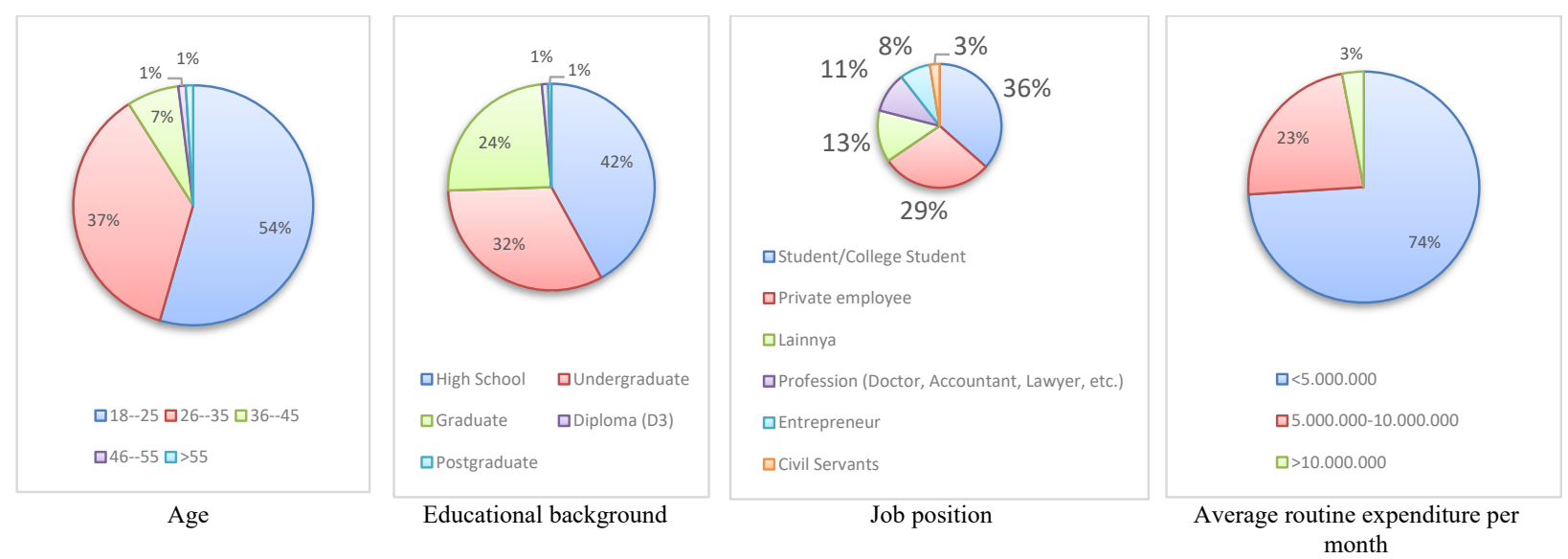

Fig. 1. Respondents Characteristics

It is known that 54.5 percent of the total 200 respondents were between the ages of 18 and 25 . Respondents with a high school diploma or equivalent have the highest percentage of 42 percent. Respondents with student status have the highest percentage of 36.5 percent when compared to other types of work. Furthermore, $74 \%$ of respondents have an average monthly routine expenditure of less than IDR 5,000,000. The validity test is carried out to determine whether the indicators used are valid in a questionnaire. The validity test was carried out using the Pearson correlation between indicators and the number of indicators per respondent, then the Pearson correlation value in this study was shown by the calculated R-value which would then be compared with the r-table value with a significance level of $\alpha=0.05$ and N-2 degrees of freedom. An indicator is declared valid if the calculated $r$ value is more than the $r$ table value. The results of the validity test show that the overall $r$ count of indicators is more than $r$ table, so it can be stated that all indicators are valid and can be used for further analysis. Reliability test is a test used to ascertain whether the research questionnaire to be used can collect reliable research data or not. The questionnaire is declared reliable if the questionnaire is re-measured, it will get the same results. In this test, the reliability test was carried out by looking at the Cronbach's Alpha value, if the Cronbach's Alpha value was more than 0.6 then the questionnaire was declared reliable. The result of Cronbach's Alpha in the questionnaire used for this study was 0.952 , where this value is more than 0.6. So that it can be stated that all the variables used are reliable and the data obtained can be continued at the next analysis stage. The result of Cronbach's Alpha in the questionnaire used for this study was 0.952 , where this value is more than 0.6. So that it can be stated that the questionnaire used is reliable and the data obtained can be continued at the next analysis stage. Evaluation of the measurement model must be carried out before the latent variables with the structural model are tested. This aims to verify the indicators and latent variables can be tested further. This test is done by looking at the reliability indicator value which shows the variance of the indicator which can be explained by the latent variable. An indicator must be eliminated if the loading factor value $(\lambda)$ is less than 0.4. Based on the test results, it is known that all indicators have a loading factor value of more than 0.4 , so it can be said that all indicators that make up all variables are valid. So that overall, it can be said that the indicators used to measure each latent variable in the model are quite optimal. Based on the root value of the AVE and the correlation coefficient of the latent variable, it can be seen that the AVE root value of all variables is higher than the correlation value of that variable with other variables. An example is the ATU variable has an 
AVE root value of 0.922 while the correlation value of the ATU variable with other variables such as the Intention to Reuse (IR) variable, Perceived Ease of Use (PEOU), Perceived Usefulness (PU), and the trust variable have a value of less than 0.922. So it can be concluded that all construct variables in the model meet discriminant validity. Furthermore, the measurement of composite reliability or convergent validity (AVE) is carried out. This measurement aims to evaluate the outer model (the variables used). Based on the AVE value, all latent variables have an AVE value above the minimum criterion of 0.5 (Ghozali, 2016). So it can be said that the criteria for convergent validity have been met or the construct variables are valid. Based on the CR value presented in the table, it is found that the 5 variables used have a CR value above 0.66 (Ghozali, 2016). which means that the indicators used can measure latent variables (constructs) properly or it can also be said that the overall measurement model is reliable. After taking measurements for the outer model (all construct variables and indicators), then measurements are taken for the complete structural model (inner model). This measurement is done by looking at the $\mathrm{R}$ square $\left(R^{2}\right)$ value of the endogenous construct. $R^{2}$ values of $0.67,0.33$ and 0.19 for endogenous latent variables in the structural model can judge that the model is "good", "moderate" and "weak" (Ghozali, 2016). Based on the results of the R-square value for each endogenous variable carried out, the Attitude Toward Use (ATU) variable has an R square of 0.773 which means that the model can only explain the ATU construct of $77.3 \%$. The Intention to Reuse variable has an R square value of 0.606 , which means that the model is only able to explain the IR construct of $60.6 \%$. Meanwhile, the PU variable has an R square value of 0.691 , which means that the model can only explain the PU variable by $69.1 \%$. All R-square values in the table also explain that each model is included in the good model except for the IR variable which is still in the moderate model category. Moreover, f square is used to measure the relationship between exogenous variables and endogenous variables.

Table 1

The Relationship Between Exogenous Variables and Endogenous Variables

\begin{tabular}{lll}
\hline & F-square & Information \\
\hline $\mathrm{ATU} \rightarrow \mathrm{IR}$ & 1.535 & Big \\
$\mathrm{PEOU} \rightarrow$ ATU & 0.039 & Weak \\
$\mathrm{PEOU} \rightarrow$ PU & 0.808 & Big \\
$\mathrm{PU} \rightarrow$ ATU & 0.185 & Medium \\
Trust $\rightarrow$ ATU & 0.359 & Big \\
Trust $\rightarrow$ PU & 0.030 & Weak \\
\hline
\end{tabular}

Based on the baseline to determine the f-square, it is known that the criteria for f-square are $0.02,0.15$ and 0.35 . The structural model can judge that the predictors of latent variables have a "weak", "medium" and "large" effect. Based on the table, the Trust variable is weak in explaining the perceived usefulness variable. The same thing happened to the PEOU variable which explained the ATU variable weakly. Meanwhile, other variables can explain other variables well. Apart from using R-squared and F-squared, the goodness of the model can also be calculated by the value of $\mathrm{Q}^{2}$. Where if the value of $\mathrm{Q}^{2}$ is more than zero, it indicates that the model has relevant predictions, whereas if the value of $\mathrm{Q}^{2}$ is less than 0 it means that the model does not have predictive relevance. The $\mathrm{Q}^{2}$ value obtained in this study is 0.973 , so it can be said that the model prepared already has relevant and good predictions. Furthermore, the measurement of the feasibility of a measurement model is carried out by looking at the results of the t-statistical value of the path coefficient. The condition is that the t-statistical value must be greater than the critical $t$ value of 1.96 at the $5 \%$ significance level. The results of the loading factor value along with the t-statistic value obtained from the bootstrapping process with a sample size of 200 and repetitions of 10000 times are as follows.

Table 1

Hypothesis Testing

\begin{tabular}{lcccc}
\hline & Original Sample $(\mathrm{O})$ & Standard Deviation $($ STDEV) & T Statistics $(|\mathrm{O} / \mathrm{STDEV}|)$ & $\mathrm{P}$ Values \\
\hline $\mathrm{ATU} \rightarrow \mathrm{IR}$ & 0.778 & 0.033 & 23.820 & 0.000 \\
$\mathrm{PEOU} \rightarrow$ ATU & 0.183 & 0.083 & 2.209 & 0.027 \\
$\mathrm{PEOU} \rightarrow$ PU & 0.724 & 0.054 & 13.298 & 0.000 \\
$\mathrm{PU} \rightarrow$ ATU & 0.369 & 0.069 & 5.316 & 0.000 \\
Trust $\rightarrow$ ATU & 0.419 & 0.064 & 6.552 & 0.000 \\
Trust $\rightarrow$ PU & 0.140 & 0.065 & 2.150 & 0.032 \\
\hline
\end{tabular}

Based on the results of the path coefficient, the results for the Perceived Ease of Use (PEOU) variable affect the Perceived of Use variable. This is because the t-statistic value obtained is 13.298 , which is more than the $t$ significance value of 1.96 and the p-value of 0.000 , where the p-value is less than 0.05 , so it can be concluded that the perceived Ease of Use variable has a significant effect on Perceived of Use. In addition, the coefficient shown is 0.724 which means that the PEOU variable affects the PU variable positively by $72.4 \%$ or it can be said that if the level of convenience perceived by consumers is 1 unit higher, of course consumers will increasingly increase product use by $72.4 \%$. When viewed from the model, the Perceived Ease of Use (PEOU) variable which affects the Attitude Toward Using (ATU) variable has a significant effect. This decision was obtained due to the t-value of 2.209 and the p-value of 0.027 . The coefficient shown is 0.183 which means that the PEOU variable positively affects the ATU variable by $18.3 \%$. This means that if the level of convenience felt by consumers increases by 1 unit, it will increase public interest by $18.3 \%$. Based on the table, it can be seen that the PU variable that affects ATU 
has a t-count value of 5.316 with a p-value of 0.000 . So it can be concluded that the PU variable significantly affects the ATU variable. And the effect shown is a positive effect of 0.369 or $36.9 \%$.

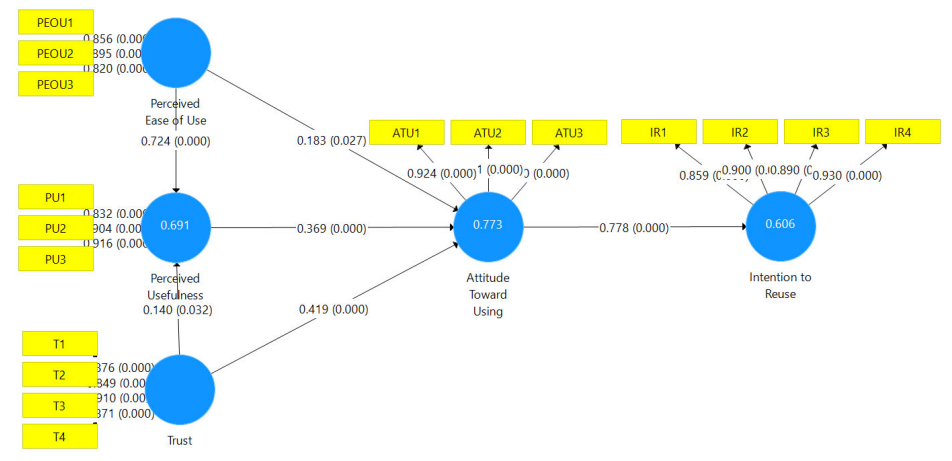

Fig. 2. Research Model

This means that the PU variable affects the ATU variable by $36.9 \%$ or it can be said that the increasing use of the product will affect the public interest by $36.9 \%$. From the path model coefficient, the Trust variable which affects the Perceived Usefulness (PU) variable has a significant effect. This decision was obtained due to the t-value of 2.150 and the p-value of 0.032 . The coefficient shown is 0.140 , which means that the Trust variable affects the PU variable positively by $14 \%$. This means that if public trust increases, it will further increase Traveloka usage by 14\%. Based on the table, the Trust variable that affects ATU has a t-value of 6.552 with a p-value of 0,000 . So it can be concluded that the Trust variable affects the ATU variable significantly. And the effect shown is a positive effect of 0.419 or $41.9 \%$. Which means that the Trust variable affects the ATU variable by $41.9 \%$ or it can be said that the increasing public trust in the Traveloka.com site will affect public interest by $41.9 \%$. Based on the results of the path coefficient, the results for the Attitude Toward Using (ATU) variable affect the Intention to Reuse (IR) variable. This is because the t-statistic value obtained is 23,820 , which is more than the $t$ significance value of 1.96 and the p-value of 0,000 , where the p-value is less than 0.05 , so it can be concluded that the ATU variable has a significant effect on IR. In addition, the coefficient shown is 0.778 which means that the ATU variable affects the IR variable positively by $77.8 \%$ or it can be said that if the public's interest in using the Traveloka.com site increases, of course it will increase the public's or consumers' intention to reuse the Traveloka.com of $77.8 \%$. If seen from the significance of the Perceived ease of use perceived usefulness parameter, as well as the truth variable, all of them have a very significant effect on the Attitude towards Using bar and also significantly influence the IR variable so that it can be concluded that the ATU variable mediates the effect of perceived Ease of Use, Perceived Usefulness., as well as truth to IR. Furthermore, a single test was also carried out to test whether the ATU variable mediated other variables towards the intention to return to the Traveloka.com website. The following are the values needed to calculate, where $\mathrm{S}$ is the standard deviation value, $\mathrm{P}$ is the coefficient value, and Se is the standard error value. Based on the results of the Sobel test, it is known that the t-value obtained is 4.749 , this value is greater than the $t$ significance level of 1.96. So it can be concluded that the Attitude Toward Using variable mediates the effect of Perceived Ease of Use on the intention to reuse the Traveloka.com website. The Sobel test value indicated by the t-count value is 7,928. Where this value is greater than the significance level of $t$ of 1.96 . So it can be concluded that Attitude Toward Using mediates the influence of Perceived Usefulness on the intention to reuse the Traveloka.com website. Based on the results of the Sobel test, it is known that the $t$-value obtained is 9,129 , this value is greater than the $t$ significance level of 1.96. So it can be concluded that the Attitude Toward Using variable mediates the influence of the trust variable on the intention to reuse the Traveloka.com website.

\section{Conclusions and Suggestion}

Perceived Ease of Use has a positive and significant effect on Perceived Usefulness from the Traveloka website. Perceived Ease of Use has a positive and significant effect on Attitude Toward Using the Traveloka.com website. Perceived Usefulness has a positive and significant effect on Attitude Toward Using the Traveloka.com website. Trust has a positive and significant effect on Perceived Usefulness from the Traveloka website. Trust has a positive and significant effect on Attitude Toward Using the Traveloka.com website. Attitude Toward Using has a positive and significant effect on the intention to reuse the Traveloka.com website. Attitude Toward Using mediates the effect of Perceived Ease of Use on the intention to reuse the Traveloka.com website. Attitude Toward Using mediates the influence of Perceived Usefulness on the intention to reuse the Traveloka.com website. Attitude Toward Using mediates the influence of the Trust on the intention to reuse the Traveloka.com website. 


\section{References}

Abdalla, I. (2007). Evaluating effectiveness of e-blackboard system using TAM framework: A structural analysis approach. Aace Journal, 15(3), 279-287.

Agarwal, A. (2019). Online Customer Experience:A Literature Review. Parikalpana: KIIT Journal of Management, 15. https://doi.org/10.23862/kiit-parikalpana/2019/v15/i1-2/190205

Arens, A. A., Elder, R. J., \& Beasley, M. S. (2008). Auditing dan Jasa Asuransi Pendekatan Terintegrasi. In Erlangga. (2nd ed.).

Ariyanto, D., Dewi, A. A., \& Jhuniantara, I. M. G. (2020). Perceived learning assistance and perceived community building assistance: Study on e-learning system. Systematic Reviews in Pharmacy, 11(12), 330-339. https://doi.org/10.31838/srp.2020.12.53

Benedicktus, R. L., \& Andrews, M. L. (2006). Building trust with consensus information: The effects of valence and sequence direction. Journal of Interactive Advertising, 6(2), 3-25.https://doi.org/10.1080/15252019.2006.10722115

Bhattacherjee, A. (2001). Understanding information systems continuance: An expectation-confirmation model. MIS Quarterly: Management Information Systems, 25(3), 351-370. https://doi.org/10.2307/3250921

Chau, P. Y., Hu, P. J. H., Lee, B. L., \& Au, A. K. (2007). Examining customers' trust in online vendors and their dropout decisions: an empirical study. Electronic Commerce Research and Applications, 6(2), 171-182. https://doi.org/10.1016/j.elerap.2006.11.008

Chen, L. D., Gillenson, M. L., \& Sherrell, D. L. (2004). Consumer acceptance of virtual stores: A theoretical model and critical success factors for virtual stores. ACM SIGMIS Database: the DATABASE for Advances in Information Systems, 35(2), 8-31. https://doi.org/10.1145/1007965.1007968

Chircu, A. M., Davis, G. B., \& Kauffman, R. J. (2000). Trust, Expertise, and E-Commerce Intermediary Adoption. Proceedings of the Sixth Americas Conference on Information Systems.

Chiu, C. M., Chang, C. C., Cheng, H. L., \& Fang, Y. H. (2009). Determinants of customer repurchase intention in online shopping. Online Information Review, 33(4). https://doi.org/10.1108/14684520910985710

Dahlberg, T., Mallat, N., \& Öörni, A. (2003). Trust enhanced technology acceptance model - consumer acceptance of mobile payment solutions. Stockholm Mobility Roundtable.

Davis, F D. (1985). A technology acceptance model for empirically testing new end-user information systems: Theory and results. Management, Ph.D.(May), 291. https://doi.org/oclc/56932490

Davis, F. D., Bagozzi, R. P., \& Warshaw, P. R. (1989). User acceptance of computer technology: A comparison of two theoretical models. Management science, 35(8), 982-1003. https://doi.org/10.1287/mnsc.35.8.982

Davis, F. D., \& Venkatesh, V. (1996). A critical assessment of potential measurement biases in the technology acceptance model: three experiments. International journal of human-computer studies, 45(1), 19-45. https://doi.org/10.1006/ijhc.1996.0040

Davis, Fred D. (1989). Perceived Usefulness, Perceived, And User Acceptance. MIS Quarterly, 13(3), 319-339. https://doi.org/10.2307/249008

Gefen, D., Karahanna, E., \& Straub, D. W. (2003). Trust and tam in online shopping: AN integrated model. MIS Quarterly: Management Information Systems, 27(1), 51-90. https://doi.org/10.2307/30036519

Ghozali, I. (2016). Aplikasi Analisis Multivariate dengan Program IBM SPSS 21 :Update PLS Regresi. Universitas Diponegoro.

Ha, S., \& Stoel, L. (2009). Consumer e-shopping acceptance: Antecedents in a technology acceptance model. Journal of Business Research, 62(5), 565-571. https://doi.org/10.1016/j.jbusres.2008.06.016

Hart, C., \& Johnson, M. (1999). Growing the trust relationship. Marketing Management.

Hoppe, R., Newman, P., \& Mugera, P. (2001). Factors affecting the adoption of internet banking in South Africa: a comparative study. ... of Cape Town, South Africa, October, 1-38. https://unileverinstitute.co.za/InformationSystems/ResearchPublications/2007/Pubs2001/ER009_Factors Affecting the Adoption of Internet Banking.pdf

Hozhabri, A., Raeesi, R., Md Nor, K., Salimianrizi, H., \& Tayebiniya, J. (2014). Online re-purchase intention: Testing expectation confirmation model ECM on online shopping context in Iran. 8th International Conference on E-Commerce in Developing Countries: With Focus on e-Trust, ECDC 2014. https://doi.org/10.1109/ECDC.2014.6836757

Hung, S. W., Cheng, M. J., \& Chen, P. C. (2012). Reexamining the factors for trust in cultivating online customer repurchase intentions: The moderating effect of perceived waiting. International Journal of Human-Computer Interaction, 28(10), 666-677. https://doi.org/10.1080/10447318.2011.654201

Igbaria, M., \& Chakrabarti, A. (1990). Computer anxiety and attitudes towards microcomputer use. Behaviour \& Information Technology, 9(3), 229-241. https://doi.org/10.1080/01449299008924239

Kim, H. bumm, Kim, T. (Terry), \& Shin, S. W. (2009). Modeling roles of subjective norms and eTrust in customers' acceptance of airline B2C eCommerce websites. Tourism Management, 30(2), 266-277. https://doi.org/10.1016/j.tourman.2008.07.001

Lim, W. M., \& Ting, D. H. (2012). E-shopping: an Analysis of the Technology Acceptance Model. Modern Applied Science, 6(4), 49. https://doi.org/10.5539/mas.v6n4p49 
Lim, Y. J., Osman, A., Salahuddin, S. N., Romle, A. R., \& Abdullah, S. (2016). Factors influencing online shopping behavior: the mediating role of purchase intention. Procedia economics and finance, 35, 401-410. https://doi.org/10.1016/s22125671(16)00050-2

Lin, C. P., \& Bhattacherjee, A. (2010). Extending technology usage models to interactive hedonic technologies: a theoretical model and empirical test. Information Systems Journal, 20(2), 163-181. https://doi.org/10.1111/j.1365-2575.2007.00265.x

Lin, C. Y., Fang, K., \& Tu, C. C. (2010). Predicting consumer repurchase intentions to shop online. Journal of Computers, 5(10), 1527-1533. https://doi.org/10.4304/jcp.5.10.1527-1533

Lui, H. K., \& Jamieson, R. (2003). TriTAM: a model for integrating trust and risk perceptions in business-to-consumer electronic commerce. 16th Bled Electronic Commerce ETransformation.

Pavlou, P. A. (2003). Consumer Acceptance of Electronic Commerce: Integrating Trust and Risk with the Technology Acceptance Model. International Journal of Electronic Commerce, 7(3), 101-134.

Ramayah, T., Rahman, S. A., \& Ling, N. C. (2018). How do Consumption Values Influence Online Purchase Intention among School Leavers in Malaysia?. Revista Brasileira de Gestão de Negócios, 20(4), 638-654. https://doi.org/10.7819/rbgn.v0i0.3139

Rehman, S. U., Bhatti, A., Mohamed, R., \& Ayoup, H. (2019). The moderating role of trust and commitment between consumer purchase intention and online shopping behavior in the context of Pakistan. Journal of Global Entrepreneurship Research, 9(1), 1-25.. https://doi.org/10.1186/s40497-019-0166-2

Rousseau, D. M. (1998). The 'problem' of the psychological contract considered. Journal of Organizational Behavior, 19, 665-671. https://doi.org/10.1002/(sici)1099-1379(1998)19:1+<665::aid-job972>3.0.co;2-x

Sevim, N., Yüncü, D., \& Eroğlu Hall, E. (2017). Analysis of The Extended Technology Acceptance Model in Online Travel Products. Journal of Internet Applications and Management, 8(2), 45-61. https://doi.org/10.5505/iuyd.2017.03522

Wen, C., Prybutok, V. R., \& Xu, C. (2011). An integrated model for customer online repurchase intention. Journal of Computer Information Systems, 52(1), 14-23.. https://doi.org/10.1080/08874417.2011.11645518

Yahyapour, N. (2008). MASTER'S THESIS Determining Factors Affecting Intention to Adopt Banking Recommender System Determining Factors Affecting Intention to Adopt Banking Recommender System; Case of Iran Supervisors : Technology.

Yousafzai, S. Y., Pallister, J. G., \& Foxall, G. R. (2003). A proposed model of e-trust for electronic banking. Technovation, 23(11), 847-860.. https://doi.org/10.1016/S0166-4972(03)00130-5

Yuan, D., Lin, Z., \& Zhuo, R. (2016). What drives consumer knowledge sharing in online travel communities?: Personal attributes or e-service factors?. Computers in Human Behavior, 63, 68-74. https://doi.org/10.1016/j.chb.2016.05.019

Zhang, J., Chiu, R., \& Wei, L. (2009). Decision-making process of internal whistleblowing behavior in China: Empirical evidence and implications. Journal of Business Ethics, 88(Supplement 1), 25-41. https://doi.org/10.1007/s10551-0089831-z 
(C) 2021 by the authors; licensee Growing Science, Canada. This is an open access article distributed under the terms and conditions of the Creative Commons Attribution (CC-BY) license (http://creativecommons.org/licenses/by/4.0/). 